\title{
Traditional and Cultural Beliefs vis-à-vis National and Religious Myths in Sohrab Sepehri's The Traveler
}

\author{
Mansoureh Ebrahimi ${ }^{1}$, Kazem Mousavi ${ }^{2} \&$ Saied Ghashghaie $^{3}$ \\ ${ }^{1}$ Faculty of Islamic Civilization, Universiti Teknologi Malaysia, Johor Bahru, Johor, Malaysia \\ ${ }^{2}$ Kazem Mousavi, Department of Persian Literature, Shahrekord University, Iran \\ ${ }^{3}$ Saied Ghashghaie, Department of Persian Literature and Language, Azad University, Fasa Branch, Iran \\ Correspondence: Mansoureh Ebrahimi, Faculty of Islamic Civilization, Universiti Teknologi Malaysia, 81310 \\ Johor Bahru, Johor, Malaysia. Tel: 60-75-55-7682. H/P: 60-14-220-1703. E-mail: mansoureh@utm.my; \\ suriebrahimi@gmail.com
}

$\begin{array}{lr}\text { Received: January 12, } 2015 & \text { Accepted: February 27, } 2015 \quad \text { Online Published: May 15, } 2015 \\ \text { doi:10.5539/ass.v11n15p180 } & \text { URL: http://dx.doi.org/10.5539/ass.v11n15p180 }\end{array}$

\begin{abstract}
This study examines the integration of national and religious myths from varied traditions that permeate Sohrab Sepehri's poem, The Traveler. The authors posit that Sepehri's conceptions of these ancient tales and their expression in the poem constitute a creative evolutionary process that stands as our central thesis. The focus is an interpretation of Sepehri's unconscious mind vis-à-vis the association of specific myths with the theosophical origins of recurrent themes. We utilize historical criticism as literary analysis in our application of a qualitative approach to the depiction of positions and periods in which these myths enjoyed currency in their respective cultures. Thus, the study attempts to portray the imaginative world that stands behind The Traveler while analyzing the relations of myths to religion, history and sociology - perhaps with a view to position the cited traditions as 'Iranian', or allow them as adaptations of traditional Persian forms derived from other nations. We conclude that the construction and interpretation of myths embody age-old existential issues and readers may judge whether the authors have substantiated the thesis of 'poetic evolution'. This novel approach to the great poet has but slight contemporary competition, hence, the literature base is meager.
\end{abstract}

Keywords: Iran, Sohrab Sepehri, The Traveler, national and religious myths, theosophy

\section{Introduction}

Literary study encompasses a panoramic view of civilization's history as literature is kind of gateway that manifests the transmission of traditions from one place to another. This essential door holds an exclusive terminology that carries the strength of myths with their archetypes on a continuum. Myths actually act as an archive of archetypes from the oldest traditions and include a uniquely expansive power that clarifies reality and the origins of existence. They are significant and inseparable components, new and old, that transmit transcendent energy to mankind's thought and powers of reflection. Doubtless, mythologists are pioneers of literature and art who play an ideological role as guides, thus, they strive to teach people how to move forward towards a more successful management of their affairs for the betterment of all social and cultural activity.

Nonetheless, myths have no rational explanation, something which passively indicates that their fundamental semantics have been, perhaps, lost to intellectualism. By definition, myths are symbolic stories of creation, gods, angels, saints, heroes, demons and other-worldly beings and creatures (Ismailpūr, 1998, p. 13). The challenge presented to many is their obvious legitimization of events that seem to connect us to other worlds that benefit metaphysical archetypes. Hence, their enduring and lasting presence and meaningful connections play a vital role worth considering also in the Persian venue.

Sohrab Sepehri is prominent Iranian contemporary poet and well known theosophist who addresses inner subjectivity and realism by connecting human beings with the natural world via theo-centric reflection. This study examines how and why national and religious myths permeate Sepehri's poem, The Traveler. We focus on Sepehri's unconscious mind while highlighting links between specific myths and the theosophical origins of mythical themes presented in his poetry. To manifest their positions and periods in different cultures and, in particular, to analyze the relation of myths to religion, history and sociology, this study attempts to clarify the 
cited myths as Iranian or perhaps adaptations of traditional forms from other nations by applying a qualitative approach to the discussion. The conclusion drawn is that the construction and interpretation of myths embody age old existential issues.

\section{National and Religious Myths in Sohrab Sepehri's The Traveler}

As the result of much travel, Sepehri became knowledgeable about the myths, religions and cultures of numerous countries. Their impressive effects were subsequently included as conceptual themes in his poetry. National and religious myths embodied in The Traveler consistently originate from different religions, although they speak to us subtly as intricate webs of linguistic skill, expertly joined to symbolic verse. For our purposes, therefore, these myths are analyzed according to their order of appearance in Sepehri's The Traveler.

Theosophists believe that one should know one's self before reaching out to attain godliness. Pursuant to such awareness, mankind is but a small essence of the manifestation of God and, without doubt, man's grief in this world is due to the separation from his origin. With insight and awareness, Sepehri was, therefore, seeking life's realities by abandoning beautiful yet mundane outer appearances in search of a hidden interior. He saw himself in a boat, which, in Indian myths, rescues human beings for the purpose of reaching far distant ideals: "May Agni carry us through all our troubles, through grief as in a boat across the river" (Griffith, 1896, 53-Veda19).

At midnight, on the ancient boat of theosophy

They set sail on the waters of guidance

And they sail on till the emergence of bewilderment (Sepehri 2004, p. 26).

-I am still on my journey

I fancy

There is a boat on the waters of the world

And I, the passenger of the boat, have been chanting

The lively song of the ancient mariners

To the ears of seasons' chinks for thousands of years

And I am sailing on (Sepehri, 2004, p. 28).

Sepehri then mentions 'Eve', precisely the lady of the same name and connotations as the ancient legend. According to Al'Qur'ān (Sūrah Al-Baqarah: 'The Cow'), Adam and his wife were forbidden to approach 'the tree':

O Adam! Dwell you, and your spouse, in the garden, and eat (of the fruits) thereof to your hearts' content where you desire, but do not approach this tree, or you will both be among the wrongdoers. But Satan (tempting them to the forbidden tree despite Our forewarning,) caused them both to deflect therefrom and brought them out of the (happy) state in which they were. And We said, "Go down, (all of you,) (and henceforth you will live a life,) some of you being the enemies of others. There shall be for you on the earth a habitation and provision until an appointed time. (Al'Qur'ān, Al-Baqarah, 2, 35-36)

The same tale appears in the Zoroastrian holy book of the ancient Parsi Prophet (Oshīdarī, 1992, p. 249). Sepehri clearly reveals that 'Eve"' had been deceived.

\section{Life is}

Eve's one-minute, colorful negligence (Sepehri, 2004, p. 34).

While advancing along his chosen road, Sepehri also sought out 'the Ronus Rock'. Some such rocks are thought to have holy aspects such as the Japanese belief that Koma is made of jade. Among archaic ethnic groups, some rocks in their natural and original state were like a god and considered holy beings. For instance, in Asia Minor, there was Cybele (Kybele), originally considered the Mother Goddess of Nature and worshipped as a sacred rock. In 204 BC, Rome built a temple for Cybele on the Palatine Hill. Also, in Canaan, Jacob, the Hebrew patriarch, used a rock as a pillow while dreaming of heaven (Hall, 2004, p. 213). Moreover, in Borhan-e Ghate, 'Ronus' (rhyming with 'Folus') is the name of a rock from which, when one wears it as a signet-ring, causes one to, allegedly, never be in sorrow (Tabrīzī, 1963, p. 966). Shamisā perceived 'runes' from which came the Greek alphabet, first engraved on stone and wood. This was also customary among Anglo-Saxons and Scandinavian peoples and bore religious overtones (Shamisā, 2003, p. 172). In this famous line, Sepehri displays sadness and sorrow; in nostalgia he engraved a memorial on a tree. 
Where is the Ronus Rock?

I come from the vicinity of a tree

On whose bark the plain hands of nostalgia

Had engraved:

"In the memory of a nostalgic feeling" (Sepehri, 2004, pp. 36-38).

Sepehri expressed one of the most tragic episodes in The Shahnameh (The Book of Kings). Sohrab was the result of a simple love between Rostam and Tahmineh, daughter of the Turanian king of Samangan in Azerbaijan. According to The Shahnameh, on the third day of wrestling between father and son-unknown to each other-Rostam gained the advantage and stabbed Sohrab's side. Sohrab then declared that Rostam, his father, would take revenge for his death and showed an onyx to Rostam. Rostam recognized the onyx as the very same one he had given to Tahmineh to bind on the arm of any son. However, hope was lost. Goodarz was sent to Kai Kawous to bring an antidote for Sohrab but he had flinty heart. Rostam then went himself to obtain the antidote and perhaps save Sohrab. But Rostam was soon informed of Sohrab's death (Firdowsī, 2007: Rustam and Suhrāb). The proverb, "After death the doctor", came from this episode. Sepehri miserably restates this tragedy and asks for wine to reduce the grief arising from the epic, one that is related to the history of genesis and the first day of the creation of everything. Hence, we can say that his sorrow is never-ending.

Pass the wine around

One should haste:

I come from a journey in an epic,

And I know

By heart

All the legend of "Sohrab and the Antidote" (Sepehri, 2004, p. 38).

However, Sepehri's grief did not leave and rather directed him to another land where he wrote of Prophet Dawud playing his lyre as recorded in the Book of Psalms:

By the rivers of Babylon, there we sat down. Yes, we wept, when we remembered Zion. On the willows in its midst, we hung up our harps. For there, those who led us captive asked us for songs. Those who tormented us demanded songs of joy: "Sing us one of the songs of Zion!" How can we sing Yahweh's song in a foreign land? (The Bible: Psalm 137).

Sepehri completely understood their beleaguered plaint and imagined himself immersed in the same sadness:

And once, under the sky of 'Psalms'

On the journey at the banks of Babylon River

When I came

There was no melody of the 'lyre'

When I listened carefully, I could hear someone weeping

And a few impatient lyres

Were swinging on the wet boughs of the weeping willow (Sepehri, 2004, p. 40).

Soon afterwards, Sepehri identifies with Prophet Jeremiah (Irmiya), the weeping prophet and messenger of Christian promises who preached in Jerusalem and prophesied its destruction. His mission was to prevent his people from committing massive transgressions, yet he was imprisoned by king Zedekiah until Jerusalem fell to the Babylonians in $587 \mathrm{BC}$. The Book of Lamentations in the Hebrew Bible is a collection of verse bewailing this fall of Jerusalem. Hopelessly, Sepehri talks of the world's futility. He also discovered similar keens in Ecclesiastes, a book belonging to a son of David.

On the route of the journey, the pious Christian monks

Pointed towards

The silent canvas of

The Prophet Jeremiah

And I read Ecclesiastes - loudly (Sepehri, 2004, p. 40). 
Along the way afterwards, Sepehri reviews 'world papers' and begins to interpret the world differently while emphasizing Hindu philosophy on the Ganges River. His clear intention was to bathe, not the body, but the soul. In Indian myths, Ganga is Goddess of the River Ganges which has its source in heaven. The sacred river is worshiped by millions of Hindus who ritually bathe in it. They have come to believe that the ritual purifies the soul and grants remission of sins. In fact, many ancients the world over commonly believed that water held the origins of life (Campbell, 1962, pp. 435-436).

After ten years of rigorous self-discipline in the Himalayas, Siddhartha Gautama moved from Sarnath Road to Varanasi, known as Banaras, a city on the banks of a river; “... there the Buddha sat under the Bodhi tree and vowed not to get up until he was enlightened" (Snyder, 2009, p. 46) After that he went to Banaras and delivered four evolutionary stages of religion including devotion, discipline, tranquility and understanding (wisdom). By means of the philosophy of the innovative outlook, Sepehri puts the dust of habit away and views the world anew. By looking at Buddha's statues with its ornamental ears, Sepehri then described Buddha's secret for Varanasi's girls:

I am the interpreter of the sparrows of the valley of 'Ganges

And I have interpreted the mystic signed earrings

Of Tibet to the ornamentless ears of Banarass girls

Alongside the Saranat Road (Sepehri, 2004, p. 50).

Led by sentiment, Sepehri talks of the Vedic hymns from Hinduism's ancient holy books, including four large canonical volumes in Sanskrit ( 1200 BCE), The Rig Veda, The Yajur Veda, The Sama Veda, and The Atharva $V e d a$. Of these Vedic texts, The Rig Veda is the oldest historical monument and more worthy, consisting of hymns of praise and controversy between gods and legendary beings (Shāyigān, 1983, p. 44). In terms of linguistics and culture, The Rig Veda is very similar to the Iranian Avesta, a sacred book containing five volumes: the Yasna (including the Gathas), Visperad, Vendidad, Yashts, and Khordeh Avesta. Sepehri points to the Hindu Vedic Fire Ceremony; a ritual of yanji known as havan, homa or Agnihorta. It initially begins with a recitation of hymns from the Atharva, Rig and Sama Vedas. The supplicants then place gifts into a sacred fire to Agni (the fire God) (Hizāreh, 2004, pp. 97-98).

O morning hymns of 'the Vedas'!

Pull all the weights of freshness on my shoulders

Since I am

Desirous to talk (Sepehri, 2004, p. 50).

Since Sepehri felt on 'top of the world' and eager to talk, he then turns to Prophet Moses on Mount Sinai. According to Al'Qur'ān, Sūrah Ṭā. Hā:

Has the report of Moses come to you ...when he saw a fire, and so said to his family: "Wait here! Indeed I perceive a fire far off. Perhaps I can bring you a burning brand from it, or find guidance by the fire." Then when he came near to it, he was called by name: "O Moses! Indeed it is I, I am your Lord. So take off your sandals, for you are in the sacred valley of Tuwā”" (Al'Qur'ān, Țā. Hā, 20, 9-13).

Also according to Al'Qur'ān, (Sūrah Maryam) Moses the Kalimullah ('one who speaks with Allah') was a prominent messenger who talked to Allah: "We called out to him from the right side of Mount Sinai, and drew him close for communication" (Al'Qur'ān, Maryam, 19, 52). Sepehri, the lonely traveler who had recently visited Mount Sinai, wistfully desired a similar address by a similar voice speaking through olive trees on a Palestinian mountain side - as if he too, was a Kalimullah.

$\mathrm{O}$ all olive trees of Palestine!

Address to me all the abundance of your shades

To this lone traveler who has come

From the journey around Mount Sinai

And is impatient of the heat of 'talk' (Sepehri, 2004, p. 50).

Sepehri then tended to the birth of the Zoroastrian promise; a man whose advent would announce a millennium of righteousness on earth. As written in the Avesta, a world savior (an Iranian prophet) was to incredibly have three sons born after his death. In a dictionary of legends, Saošyant, the promised Zoroastrian savior, is Zoroaster's son born at the beginning of Judgment Day. His mission is to raise the dead and prepare them for an 
everlasting life full of brightness (Yāhaqī, 1990, p. 260). According to the Avesta, the seeds of the prophet were preserved in Lake Kãsava, also known as Kąsaoya (Hamun Lake).

At the appointed time, it will be united again with a maternal womb: 99,999 Fravashis of the faithful watch over it, lest the fiends destroy it (Darmesteter, 1880: Bund. XXXIII; Eznik Yast XIII 61; vendîdâd XIX 5).

Based on Zoroastrian belief, a virgin will bathe in this lake at the appointed time and become pregnant with a child by the prophet. She will give birth to a son, Astvat.ərəta, who represents justice and fairness. "Astvat.ərəta will be Saošyant, the Savior who will bring about Frašō.kərəti, smiting both "daēvas and men" (Boyce, 1975, p. 282). Eventually, in the final battle with evil, Saošyant will be miraculously won. Here, Sepehri awaits the revival and restoration of happiness for the world and human beings.

At the banks of 'Hamun', one still may hear:

-Evil has contaminated the earth

-One thousand years passed

-No one has heard the wash of a bathing

And no water has reflected the figure of a maiden (Sepehri, 2004, pp. 52-54).

Halfway through his journey, Sepehri writes of the River Jumna, also known as Yamuna, one of the seven sacred rivers in Hinduism. The source of the Jumna is in the Himalayas, a Mountain known as Yamunotri. As the largest branch of the Ganges, the Jumna is especially clear and transparent with good quality water and connects with the Ganges at Allahabad. This same river is also mythical and holds onto the legend of a girl and a boy found inside a fish - or rather, a nymph. In the Indian Golden Age, perhaps 400 BC, King Vasu was overcome by crisis when hunting and thought it best to preserve his seed. He therefore placed his seed in a leaf and called on a hawk to send it to his wife "who is in her season". Along the way, a second hawk intervenes and the seed falls into the Jumna river. The seed is "immediately swallowed by a fish, who is actually a nymph under enchantment." Some ten months later, a boy and a girl are found inside the fish by an appropriately astonished fisherman (Campbell, 1962, pp. 327-329).

Here, Sepehri ignores appearances and offers a loftier interpretation. He evidently saw the Taj Mahal by the clear waters of the Jumna. He seems to reveal the magnificent power of a waterway that carries life's summit along with death and destruction, and then digs deeper than the myth by suggesting that real bliss is met only after death. He further posits that a small spark is all one needs to enlighten inner darkness. Hence, with such an escape from shadows of gloom, man can be filled with brightness and view life anew with profoundly uncomplicated joy.

On the half way of the journey, on the coast of 'Jumna

I was sitting

Looking at the reflection of Taj Mahal in water:

The marble constancy of elixir moments

And the protrusion of the volume of life in death

Lo! Two large wings

Are traveling towards the edge of water's spirit

There are some strange sparks next to the arms

Come and light the darkness of perception

One hint only suffices (Sepehri, 2004, p. 54).

Sepehri claim that access to 'real life' is gained when just a particle of light destroys darkness is reiterated by his claim that it can also be attained by the sound of a pebble striking the rock of 'Maghar'. According to Greek myths, in the ancient Greek City-State of Megara, there was a rock that, when hit by gravel or a small stone, caused a sound exactly like that of a lyre. Allegedly, the reason was that Apollo, the Greek god of music, was playing a golden lyre and had laid it down on that very spot (Pausânias, n.d., p. 225). The implication being that the powers of a human being's mind and thought are able to ruin the darkness.

Life is a tender stroke

On the rock of 'Maghar' (Sepehri, 2004, p. 54). 
Towards the end of his travels, Sepehri once more affirms that tales of man's creation are rooted in ancient myths. Indeed, the Totem or 'spirit-being' is related to the Neolithic period. Totemism is an ancient phenomenon in which each man bears a spiritual connection to a Plant Totem named Rhubarb, also called Ribas, a species of the polygonaceous family. In Aryan belief, the father and the mother of mankind, Mashya and Mashyana were created from Ribas. In the Zoroastrian creation myth, Gayōmart, also known as Keyumars, the progenitor of mankind, was the first man. At the time of his death, two drops of his semen fell to the ground and were fertilized by the sun and kept in the soil. Forty years later, a plant, like two attached rhubarbs, sprouted and grew in the month of Mehr (the Day of Mehregan). Afterwards, the plant became two people, Mashya and Mashyana, identical twins. After fifty years they married, and after nine months a male and female were born. In due course, seven pairs of girls and boys were born from the first pair, accordingly (Oshīdarī, 1992, pp. 435-436). The same belief is found in the Bundahishn, the Zoroastrian Cosmogony of Primal Creation.

We thought

We were floating

Amidst the mythical context of Ribas convulsion

And that few seconds of negligence

Caused our Being (Sepehri, 2004, p. 58).

Finally, Sepehri discovers the secret of actual life. His only request was:

And show me

The presence of a tender 'Naught' (Sepehri, 2004, p. 64).

\section{An Overall Analysis of The Traveler}

Sepehri's searched out reality by using Indian, Greek, Middle Eastern and Iranian myths. His poetic perspective embraced those referring to prehistory and he took a fresh look at approaches like that of Krishnamurti's, an Indian mystic philosopher. Sepehri's observant skills allowed him to craft a more dynamically transcendent synthesis of mythical theosophy as he attempted to identify 'the worlds' and rightly discern secrets of eternal life. $\mathrm{He}$ is, therefore, a rather purposeful traveler who passes through the material world solely to attain the ideal. In The Traveler, Sepehri begins with a mental journey that accomplishes a universally valid tour de force.

The Traveler symbolizes mankind in a mundane world that never stops its interweave with creation from birth till death along a continuum leading even to its end. Sepehri, the traveler, also never stops anywhere along the way. He is a man on a mission who goes 'everywhere' to stay but a short time 'somewhere' only to continue on to 'somewhere else' (Turabī, 2003, p. 155). Sepehri's spiritual travel, however, is internal. He demands entry to the inner truth of things in his Adamic search for essence in nature, for objects and archetypical elements. He desires synthesis, a teleiogenic tapestry that grasps life's secrets by relating truth and The Creator by means of a physical journey that empirically unifies the essence of nature with that of divine intention. Sepehri's spiritual path was, therefore, an empirical scientific template founded on knowledge and experience. Hence, his poem's procession informs his spiritual progression.

\section{Conclusion}

Literature, particularly the theosophical, plays an essential role in the transmission of traditions. As these latter highlight some historical aspects, the literature, religion, art and culture of any nation can be observed in its myths. Hence, Sepehri's The Traveler reveals one of the most effective elements of theosophy. This investigation of Sepehri's mythical frame of mind described his worldview by bringing it to life as a sensibly oriented stream of observation. By applying himself to myths, Sepehri's purpose was spawned from his deeply veiled desire to know God through the gauging of himself and the environment. His mythical expressions propound matters of mankind's journey through life by looking upon internal layers more than the external shells of legend. Thus, the expansion of Sepehri's myths is broad enough to comprise interdependent correlations between mythology and his poetry; especially since The Traveler actually holds seventeen national and religious myths.

Without doubt Sepehri's immense outlook derived from an absolute practice of tradition. Invoking God in traditional literary manners has enormous influence on society. Fundamentally, the majority of Iranians are, indeed, traditional and religious folk and are easily moved by religious messages. The Iranian culture and religion have an antiquity of thousands of year and Iran's people have been influenced through myths even during modernity's turn at the wheel of development because these are part and parcel of generations on generations of religious belief. 
Impressively, Sepehri's poems have been translated into several languages. Thus, the legacy of his feelings, values and ideas are gently being transferred to the other nations and cultures. Globalization will ultimately pave new avenues of important developments in modern poetry, and thus, may fundamentally facilitate the transmission of tradition to the future while their lingering practices display patterns in theosophical settings. Their wandering advents and functions will, therefore, continue to transmit wonder along beaten paths of introspection, made smoother by travelers like Sepehri.

\section{Acknowledgements}

We offer sincere appreciation to Dr. Omar Zaid, M.D., Editor, Sr. Lecturer, Morals, Ethics and Values, UNITAR International University, KL, Malaysia, for his valuable editing of this paper.

\section{References}

Al'Qur'ān: Annotated Interpretation in Modern English by Ali Ünal.

Boyce, M. (1975). A History of Zoroastrianism: The Early Period (Vol. 1). E. J. Brill, Leiden, Netherlands.

Campbell, J. (1962). The Mask of God: Oriental Mythology. Martin Secker \& Warburg Limited, London.

Darmesteter, J. (1880). Sacred Books of the East (Vol. 4, The Zend-Avesta, The Vendidad (trans.)). Oxford University Press.

Firdowsī, A.-Q. (2007). The Shāhnāmeh (The Book of Kings). Qatreh Publications, Tehran, Iran.

Griffith, R.T. H. (trans.) (1896). The Hymns of the Rig Veda (2nd ed.). Kotagiri (Nilgiri), India.

Hall, J. (2004). Illustrated Dictionary of Symbols in Eastern and Western Art (Ruqīeh Behzādī, trans., 2nd ed.). Mu'āsir Publications, Tehran, Iran.

Hizāreh, D. (2004). Black \& White (1st ed.). Paž Publications, Mashhad, Iran.

Ismailpūr, A.-Q. (1998). Myth, Symbolic Expression (Ostūreh, Bayān-e Nimadīn) (1st ed.). Sorūsh Publications, Tehran, Iran.

Oshīdarī, J. (1992). An Encyclopedia of Zoroastrianis. Markaz Publications, Tehran, Iran.

Pausânias. (n. d.). Pausanian's Description of Greece (Translated by W. H. S. Jones, M.A., St. Catharine's College, Cambridge, William Heinemann in 1918, London).

Sepehri, S. (2004). The Traveler \& We Nothing but Look. Abbas Zahedi, trans., Zabānkadeh, Tehran, Iran.

Shamisā, S. (2003). Nigāhī be Sepehri (8th ed.). Sidāye Mu'āsir Publications, Tehran, Iran.

Shāyigān, D. (1983). Religions and the Theosophical School of India (3rd ed.). Amir Kabir Publications, Tehran, Iran.

Snyder, D. N. (2009). The Complete Book of Buddha's Lists-Explained. Vipassana Foundation (A non-profit organization), Las Vegas, Nevada, U.S.A.

Tabrīzī, M. H. I. K. (1963). Borhan-e Ghāte (2nd ed.). Tehran, Iran.

The Bible (King James Version).

Turabī, Z. (2003). Sohrabi Dīgar (New Look to Sohrab Sepehri’s Poetry) (1st ed.). Nigāh Publications, Tehran, Iran.

Yāhaqī, M. J. (1990). Encyclopedia of Myths (Asātir va Eshārāt-e Dāstāni) in Persian Literature (1st ed.). Mutāle'āt va Tahqīqāt-e Farhangī Institution, Tehran, Iran.

\section{Copyrights}

Copyright for this article is retained by the author(s), with first publication rights granted to the journal.

This is an open-access article distributed under the terms and conditions of the Creative Commons Attribution license (http://creativecommons.org/licenses/by/3.0/). 